\title{
Provenance and Technology of Lithic Artifacts from the Teouma Lapita Site, Vanuatu
}

\author{
$\boldsymbol{\Delta} \cdot \boldsymbol{\Delta} \cdot \boldsymbol{\Delta}$ \\ CHRISTIAN REEPMEYER, MATTHEW SPRIGGS, \\ STUART BEDFORD, AND WALLACE AMBROSE
}

\section{INTRODUCTION}

The Teouma Lapita site in southern Efate (Fig. 1) was located in 2004 (Bedford et al. 2006). During three field seasons completed to date (2004-2006), 48 burial features have been discovered, some in direct association with decorated Lapita pots, a unique situation in more than 200 Lapita sites excavated throughout the western Pacific (Bedford et al. 2009). This paper describes the flaked lithic assemblage from the Teouma site and discusses its cultural significance. It concentrates on provenance studies of the obsidian artifacts and an overview of the technological analysis of the flaked lithic artifacts in general, which will be addressed in more detail in a separate study (Reepmeyer 2009).

Extensive research on the obsidian sources in the Pacific has identified the transport of West New Britain obsidian throughout Near Oceania and into Remote Oceania and Island Southeast Asia during Lapita times (Bellwood and Koon 1989; Best 1987; Sand 2000; Summerhayes 2009; Torrence et al. 1992). Until recently there were only a few large assemblages known outside the Bismarck Archipelago (cf. Green 1987). These included Lapita sites on or near Buka Island at the northern end of the main Solomons in Near Oceania (Wickler 2001), and three main Lapita sites in the Reefs-Santa Cruz group across the boundary into Remote Oceania. With the exception of these latter sites the occurrence of this raw material has proven exceptionally rare across that boundary. Only a handful of West New Britain obsidian artifacts were known from Lapita sites in Vanuatu, New Caledonia, and Fiji (Ambrose 1976; Best 1987; Sand 2000).

The situation has now changed as far as northern and central Vanuatu are concerned. As well as Teouma, the recently reported Lapita site of Makue, Aore Island, northern Vanuatu, has produced a sizable amount of West New Britain

Christian Reepmeyer, Stuart Bedford and Wallace Ambrose are affiliated with Archaeology and Natural History at the Australian National University in the College of Asia and the Pacific, where Dr. Christian Reepmeyer is a post-doctoral Fellow, Dr. Stuart Bedford an ARC QEII Fellow and Dr. Wallace Ambrose a Visiting Fellow. Dr. Matthew Spriggs is a Professor of Archaeology at the Research School of Humanities in the College of Social Sciences, The Australian National University. 


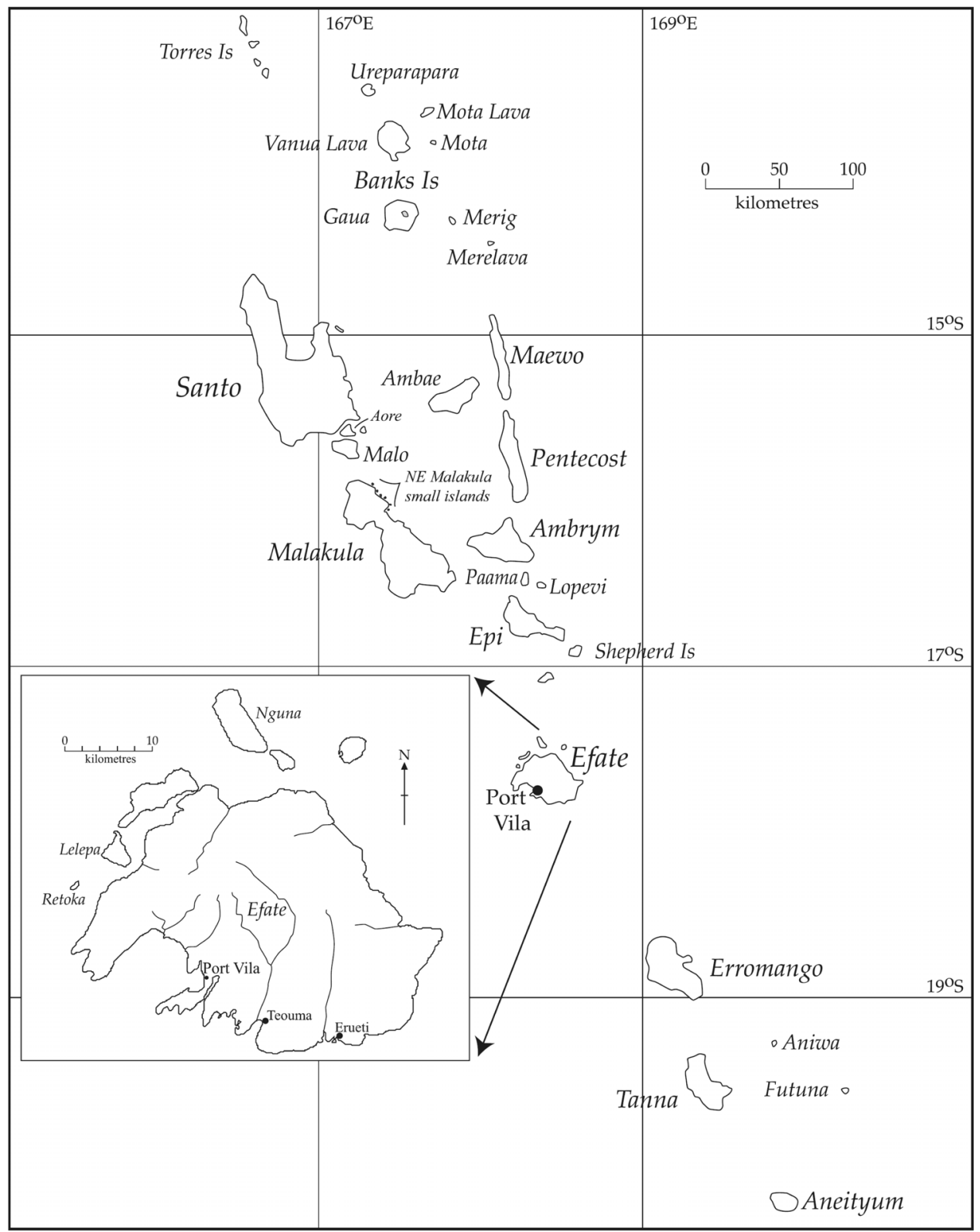

Fig. 1. Map of the Teouma site location in southern Efate, Vanuatu.

obsidian artifacts, sourced using density analysis (Galipaud and Swete-Kelly 2007). Current research indicates that the transport of West New Britain obsidian in any quantity outside of New Britain to the south and east was limited to the colonization phase of the Lapita migration (Sheppard 1993; Summerhayes 2009). However, later contact with the Bismarck Archipelago may be evident through occasional import of Admiralty Islands obsidian into sites in the Reefs-Santa Cruz 
Islands and on Tikopia in the southeast Solomons (Green 1987; Kirch and Yen 1982; see also Reepmeyer 2009; Spriggs et al. submitted).

From the five known obsidian subsources in West New Britain, it was thought that only products from the source of Kutau/Bao (previously known as Talasea) were exported outside of the Bismarck Archipelago. Obsidian from the subsources of Baki, Gulu, Hamilton, and Mopir were restricted in distribution to the Bismarck Archipelago (Torrence and Summerhayes 1997). Additionally, Mopir obsidian is not associated with early and middle Lapita assemblages in West New Britain, as the Mount Witori eruption at 3480-3150 B.P. (modal date 3315 B.P.) (Lentfer and Torrence 2007; Petrie and Torrence 2008:740) caused widespread destruction and covered this subsource (Torrence et al. 2000). However, it re-appears at the end of the middle and into the late Lapita phase in West New Britain and at sites on Watom, off the coast of East New Britain (Anson 2000).

\section{SITE DESCRIPTION}

Since the discovery of the Teouma site in 2004 three field seasons have resulted in the excavation of $275 \mathrm{~m}^{2}$. Only a short summary of the already described (Bedford et al. 2004; 2006, 2009) stratigraphy of the site will be given here. The three field seasons concentrated largely on the cemetery area, to recover information from areas that had been damaged by quarrying but not completely destroyed. Renewed research in 2008 is focusing on the settlement deposits and the overall stratigraphy of the site (Bedford et al. 2009:220).

Teouma is situated on an uplifted reef terrace approximately $800 \mathrm{~m}$ inland from the current shoreline. Shortly before initial human settlement a tephra deposit leveled out the reef terrace, so that burials had to be dug into the tephra in recesses of the reef bedrock, as well as into upper beach deposits immediately adjacent. There is some evidence, still under investigation, for a contemporary small-scale settlement focus immediately to the east of the cemetery area. After the initial period of cemetery use, there was a hiatus in use of the site. Settlement deposits of up to one meter were later deposited on top of the burials, seemingly after the earlier function of the site was forgotten or discounted.

Layer discrimination in the cemetery area is difficult as burial in-fills are generally indistinguishable from the unweathered tephra into which they were dug. The overlying occupation horizon is in contrast very distinctive with only a thin transition zone between the two. The earliest use of the site was probably around 3100-3000 B.P. (Layer 3) with an Erueti phase occupation phase commencing after about 2800 B.P. (Layer 2) (Bedford et al. 2006:818). The site was abandoned no later than 2500 B.P. as no late Erueti (c. 2500-2300 B.P) pottery has been recovered.

\section{GEOCHEMICAL ANALYSIS}

\section{Obsidian}

In this study the method of Laser Ablation-Inductively Coupled Plasma-Mass Spectrometry (LA-ICP-MS) was employed to chemically characterize solid rocks (for detailed experimental setup and methods used, see Longerich et al. 1996; 
Reepmeyer 2008, 2009; Speakman and Neff 2005). Mass spectrometry allows the analysis of a wide range of elements, including major, minor, and rare earth elements. Additionally, X-ray analysis was employed to analyze geochemically the major element distribution in the samples and as an external calibration method for the mass spectrometry using $\mathrm{SiO}_{2}$. The count rates for all elements are ratioed to silica, and the average of the laser on element/Si ratio is multiplied by the $\mathrm{SiO}_{2}$ content of the glass.

Analysis of the samples was conducted using an AGILENT 7500S Inductively Coupled Plasma-Mass Spectrometer combined with an EXIMER laser ablation system. A laser diameter of $86 \mu \mathrm{m}$ was chosen. Counts for 39 isotopes were determined by calculating the mean counts for each element from three runs. For multivariate statistical analysis SPSS and the C2 package were employed (Juggins 2005; SPSS 2000). Absolute ppm counts of isotopes were processed using logarithmic (lg) transformation and then analyzed using Principal Components Analysis (Baxter 2006). In addition, samples were analyzed using a JEOL JSM6400 Scanning Electron Microscope with an Oxford ISIS Energy-Dispersive X-ray Analyser (SEM-EDXA). Oxford instruments Link ISIS 3.3 software was utilized. Calibration was conducted using the NIST612 and the ANU2000 standard, which is a high-quality obsidian from Wekwok, Admiralty Islands (Summerhayes 2009).

For the comparison study of the Teouma artifacts, 117 obsidian samples analyzed with LA-ICP-MS from western Pacific obsidian sources were used (Reepmeyer 2009). The isotopes of ${ }^{31} \mathrm{P},{ }^{59} \mathrm{Co},{ }^{147} \mathrm{Sm},{ }^{158} \mathrm{Gd},{ }^{162} \mathrm{Dy},{ }^{186} \mathrm{~W},{ }^{208} \mathrm{~Pb}$, and ${ }^{232} \mathrm{Th}$ were selected using multiple regression analysis, as they showed the highest ranking in differentiating these sources from each other. Principal Component Analysis (PCA) was employed as an unsupervised discrimination method. PCA helps to reduce the complexity in a multi-variable data set. It orders cases in relation to their similarity and dissimilarity with other cases along vectors, so-called components. In this study the first and second components of the PCA (Fig. 2) represent 81.6 percent of the variance, providing an unambiguous separation of sources and the allocation of artifacts to certain sources. The occurrence of four different sources can be detected. Besides the relatively large number of artifacts from the West New Britain source locality Kutau/Bao, the sources of Mopir (also West New Britain), and Vanua Lava and Gaua (both in the Banks Islands), can also be identified. The results are supported by bi-plots of selected major and trace elements (here $\mathrm{K}_{2} \mathrm{O}, \mathrm{Pb}, \mathrm{Rb} / \mathrm{Sr}, \mathrm{Ta} / \mathrm{Th}$ ) (Fig. $3 a-c$ ).

\section{Location on Site}

In the 2004-2006 field seasons, areas which were disturbed by recent quarrying activities were targeted. Consequently a number of the obsidian artifacts discovered cannot be attributed to exact time periods. Additionally there is a scatter of obsidian outside the main site area and here it is only rarely possible to assign pieces to earlier or later phases as the deposits are shallow and mixed by prehistoric and/or recent agricultural activities. Considering these site disturbances only a tentative chronological assignment can be given. Further excavation of $49 \mathrm{sq} \mathrm{m}$ in undisturbed stratigraphy during 2008, however, strongly suggests that all of the recovered obsidians were originally derived from Layer 3 early Lapita deposits as no obsidian was found in any later deposits. It is therefore considered that any 


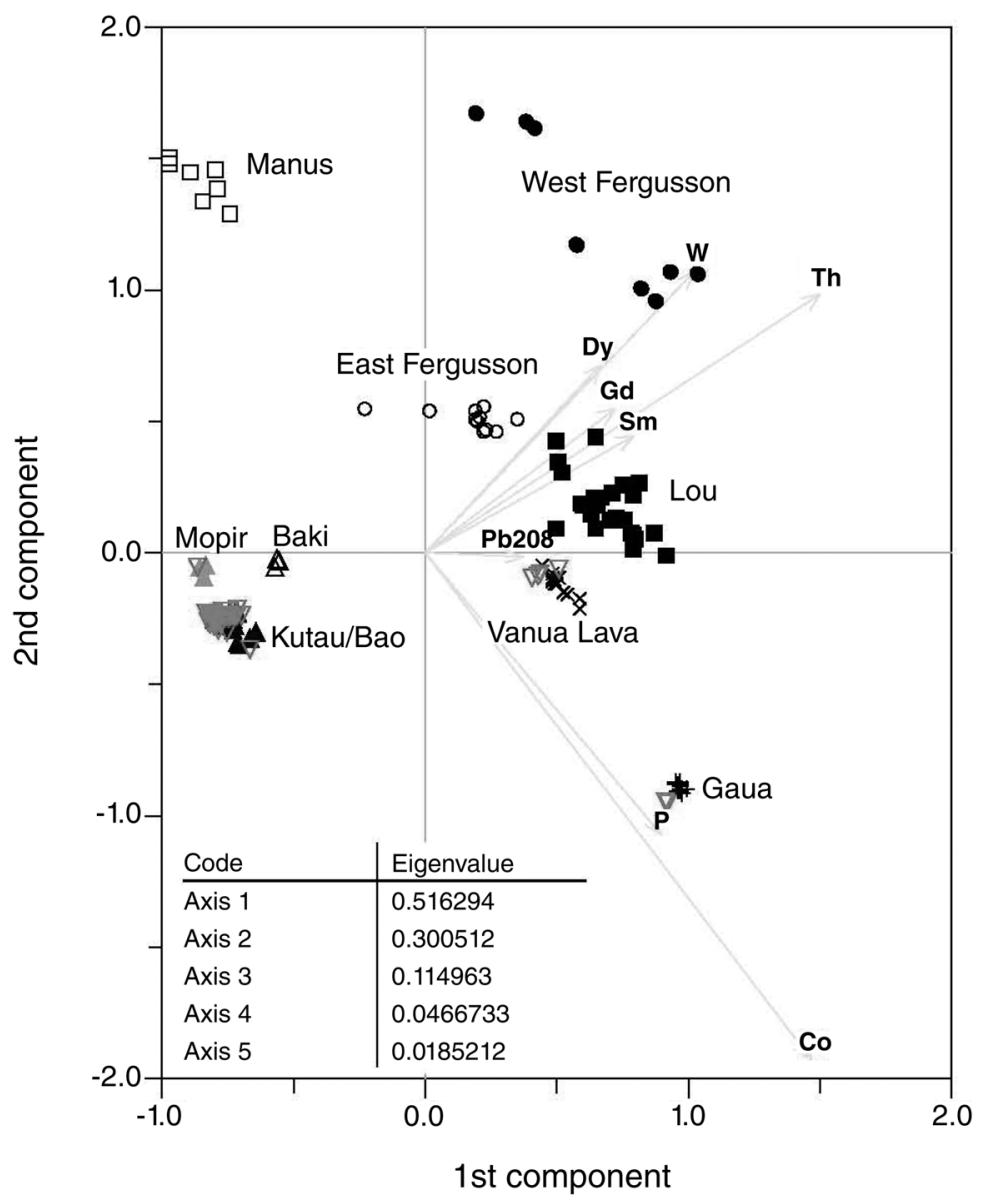

Fig. 2. Principle Component Analysis of 117 source samples from western Pacific sources and artifacts from Teouma, Vanuatu $(\boldsymbol{\Delta}=\mathrm{Kutau} /$ Bao source; $\boldsymbol{\Delta}=$ Mopir source; $\Delta=$ Baki source; $\boldsymbol{\square}=$ Lou sources; $\square=$ Manus source; $\bigcirc=$ west Fergusson sources; $\bullet=$ east Fergusson sources; $+=$ Gaua source; $\times=$ Vanua Lava source; $\nabla=$ Teouma artifacts).

obsidian found in Layer 2 Erueti deposits excavated in 2004-2006 derive from disturbed contexts and are most likely to be in secondary deposition. Erueti levels in areas of the site near the current stream, which were still below sea level in earlier Lapita times, also produced no obsidian pieces. It should be noted too that at the Arapus site in northwest Efate, in deposits contemporary with late Lapita and early Erueti phases at Teouma, not a single flake of obsidian was recovered despite extensive excavations over an area of several hectares (Bedford and Spriggs 2002; Spriggs and Bedford 2001).

\section{Surface}

Four artifacts were found on the surface, all sourced to Kutau/Bao. These artifacts could not be allocated to a specific layer as they were disturbed by quarrying and other activities on the site. 

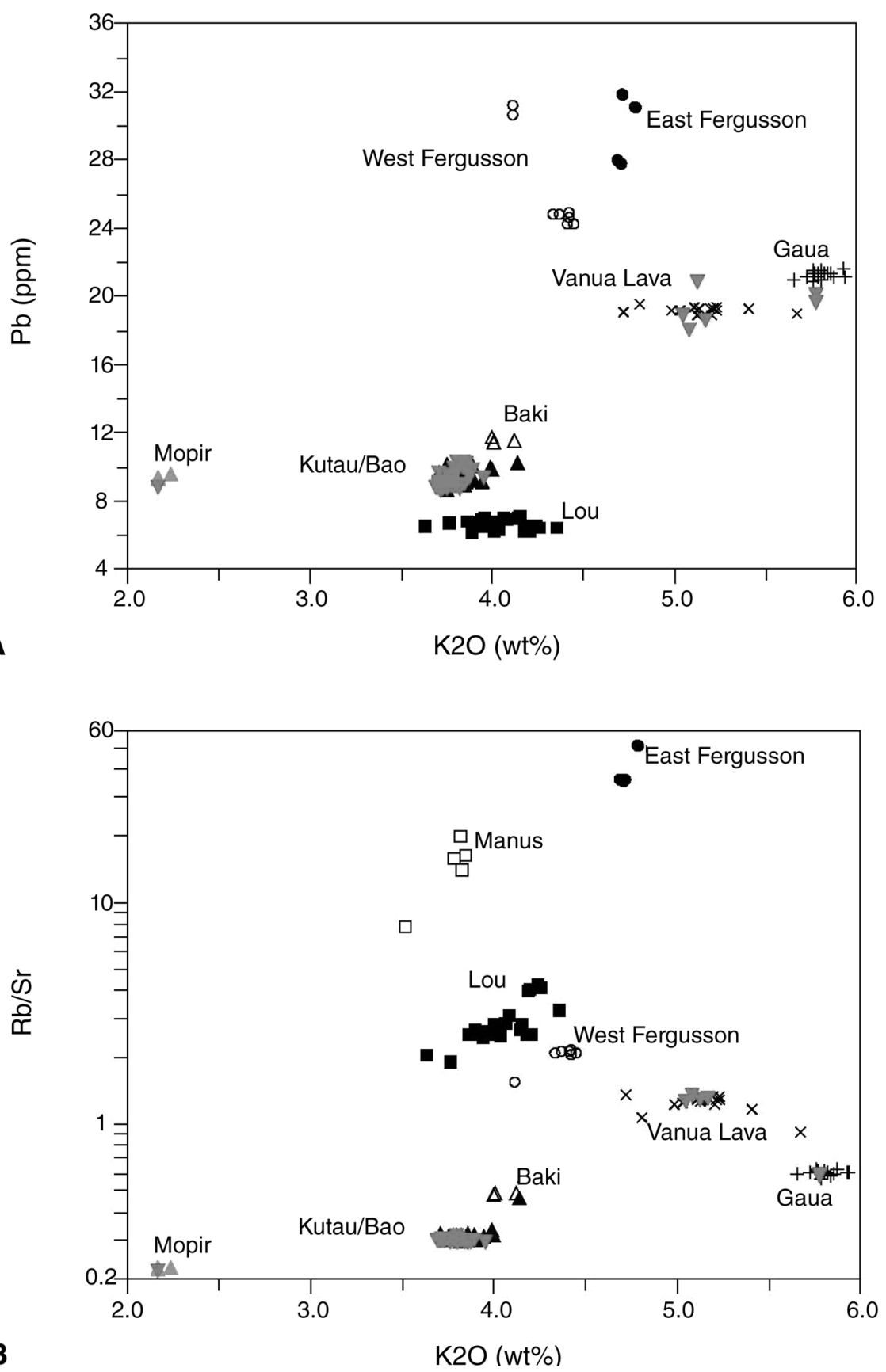

Fig. 3. Comparison of $\mathrm{K}_{2} \mathrm{O}$ abundances (wt\%) and absolute counts of (A) $\mathrm{Pb}(\mathrm{ppm})$ and ratios of (B) $\mathrm{Rb} / \mathrm{Sr},(\mathrm{C}) \mathrm{Th} / \mathrm{Ta}(\boldsymbol{\Delta}=\mathrm{Kutau} /$ Bao source; $\boldsymbol{\Delta}=$ Mopir source; $\triangle=$ Baki source; $\boldsymbol{\square}=$ Lou sources; $\square=$ Manus source; $\mathrm{O}=$ West Fergusson sources; $\bullet=$ East Fergusson sources; + = Gaua source; $\times=$ Vanua Lava source; $\nabla=$ Teouma artifacts). 


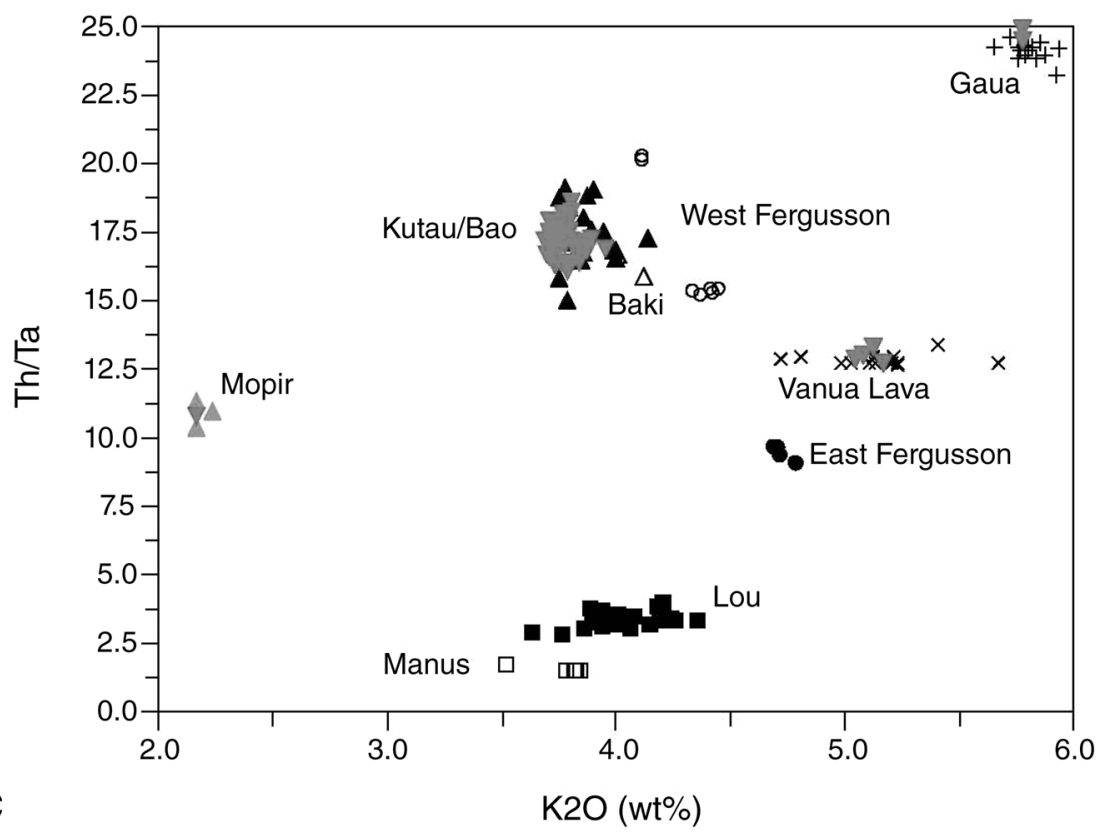

Fig. 3 (Continued)

\section{Layers 1 and 2}

As noted above, obsidian artifacts found in Layers 1 and 2 are all believed to have been disturbed from Layer 3 deposits. Layer 1 is a relatively recent gardened topsoil. In that layer, three obsidian artifacts were excavated: one from Kutau/Bao, a single artifact sourced to Mopir, and one from Vanua Lava. The Mopir piece was found outside of the main excavation area in Area 7A, in a mixed deposit with several (generally worn) potsherds including one with Erueti-type decoration. In this trench the layer was underlain by the brownish-orange tephra of Layer 3, containing worn Lapita potsherds. In Layer 2, which has been dated to the Erueti occupation phase (Bedford et al. 2006:817), nine artifacts from Kutau/Bao and one artifact from Gaua in the Banks Islands were recovered. Of the total obsidian artifact count $(n=56$, Table 1), 23.2 percent was found in Layers 1 and 2, with 84.6 percent of this attributed to West New Britain sources and 15.4 percent to the Banks Islands.

\section{Layer $2 / 3$ and $1 / 3$ Interfaces}

The top of the cemetery area was disturbed by subsequent midden activity so that obsidian pieces at the base of Layer 2 most likely originated from the underlying stratum. In one part of the site, an earlier Lapita midden component (yet to be investigated in detail) grades into later deposits without clear stratigraphic separation. Where this occurs it is again difficult to attribute pieces to precise time periods.

At the Layer 2/3 interface and in locations where only Layers 1 and 3 are present and form an interface, eight artifacts from Kutau/Bao and one artifact from 
Table i. Summary of Layer Designation of all Found Obsidian Artifacts

\begin{tabular}{llr}
\hline LAYER & SOURCE & NUMBER \\
\hline Surface & Kutau/Bao & 4 \\
1 & Kutau/Bao & 1 \\
& Mopir & 1 \\
2 & Vanua Lava & 1 \\
& Kutau/Bao & 9 \\
$2 / 3$ interface & Gaua & 1 \\
& Kutau/Bao & 8 \\
3 midden & Vanua Lava & 1 \\
& N.d. & 2 \\
& Kutau/Bao & 13 \\
3 & Gaua & 1 \\
Total & Vanua Lava & 1 \\
\hline
\end{tabular}

Vanua Lava were recovered. Additionally, there were two artifacts that showed inconsistent results in the analysis and could not be sourced unambiguously. The Layer $2 / 3$ and $1 / 3$ interfaces produced 21.4 percent of the whole obsidian assemblage. The eight artifacts sourced to West New Britain equate to 72.7 percent of the Layer 2/3 sum, 9.1 percent (1 piece) are sourced to the Banks Islands and 18.2 percent $(n=2)$ remain unsourced.

\section{Layer 3}

Layer 3 can be separated into burial fills associated with mortuary features within the cemetery area and early midden deposits to the east. The midden deposits include 15 artifacts (13 from Kutau/Bao and one each of both Banks Islands subsources). The burial fills include 12 artifacts from Kutau/Bao and one artifact from Vanua Lava in the Banks Islands. Fifty percent of the total artifact count was found in these contexts; 89.3 percent of artifacts were sourced to West New Britain and 10.7 percent to both Banks Islands sources.

\section{Chert, Basalt, and Quartz}

No separate study on the sources of chert, basalt, or quartz on Efate was conducted. Provenance studies of cherts in other sites in Remote Oceania have been carried out (Sheppard 1996), but the necessary detailed geological data for provenancing cherts are not yet available in Vanuatu. The physical attributes of the chert, basalt, and quartz artifacts, however, suggest local sources (discussion below).

\section{TECHNOLOGICAL ANALYSIS}

Fifty-six obsidian artifacts were found compared to 110 flakes, 23 angular shatter, and eight cores made from chert, quartz, and basalt. Details on the physical attri- 
butes of obsidian in comparison to chert, quartz and basalt artifacts of selected sites throughout western Remote Oceania are provided in Table 2. A more detailed statistical discussion of the physical attributes of obsidian and nonobsidian artifacts is conducted in Reepmeyer (2009).

\section{Obsidian by Source}

West New Britain (WNB) - All pieces of obsidian were small: 44 (93.3\%) artifacts are flakes and three pieces $(6.7 \%)$ were angular shatter. Three artifacts showed traces of cortex. Fifteen flakes $(25.6 \%)$ were complete; the majority of the remaining flakes $(64.4 \%)$ show transverse (6 artifacts, 13.3\%), lengthwise (5 artifacts, $11.1 \%)$, or both types of breakage (18 artifacts, $40 \%)$ (see Andrefsky 2005:87; Hiscock 2002:252-253 for definition). We cannot account for breakage as an attribute of "utilization," as neither transverse nor lengthwise breakage are unambiguous attributes for the detection of use (for discussion see Odell 1981; Shea 1988). Usually we would expect extensive use-wear and marginal resharpening resulting from the process of utilization, but these are not present in the assemblage. A possible explanation for this is that in "expedient technologies" (Hanslip 2001) deliberate abandonment of still serviceable items is not uncommon (Shott 1989a). The assemblages excavated in northern Vanuatu (Makue) as well as in the Reefs-Santa Cruz Group also displayed the same lack of use-wear and resharpening (Galipaud and Swete-Kelly 2007; Sheppard 1993). In the case of the 2004-2006 excavations of the Teouma site, WNB-obsidian artifacts could not unambiguously be associated with burials. They appear regularly in context of burial in-fills and midden deposits.

Of special interest among the Teouma assemblage are two artifacts of a type known as "gravers" (Sand and Sheppard 2000; Sheppard 1993). These artifacts were found in large quantities in the Reefs-Santa Cruz Lapita assemblages, as well as singularly in Lapita assemblages in Mussau and New Caledonia (Sand and Sheppard 2000; Sheppard 1992, 1993). They have an "alternating retouch" (Tixier 1974) of about $15 \mathrm{~mm}$ on one edge (Fig. $4 a, b)$. Between the dorsal and the ventral retouch is a c. $1 \mathrm{~mm}$ unretouched edge. Sheppard $(1993: 133)$ described this particular retouch as an intentional application, not a result of use of the artifact. No detailed use-wear analysis has been conducted yet, but obvious use-wear or edge damage are not present on the unretouched part. Sand and Sheppard $(2000: 239)$ proposed that one possible use of the graver tools was for cutting human flesh in scarification (also Hanslip 2001 : 153).

Formalized retouch is exceptionally rare apart from these two tools. Whereas edge damage is common (most probably occurring after deposition; for discussion see Young and Bamforth 1990), 33 artifacts (68.9\%) show a fine retouch on at least one edge with a continuous retouch length of more than $5 \mathrm{~mm}$. Only one further artifact could be described as carrying deliberate retouch (Fig. $4 c$ ). The single Mopir-sourced artifact is significantly larger than the Kutau/Bao pieces. It was complete, with unclear damage on one edge.

Banks Islands - Six artifacts were sourced to the Banks Islands. All of them are flakes; no angular shatter could be detected. The flakes are on average slightly larger than the WNB flakes and physically bear a resemblance to the chert flakes. 


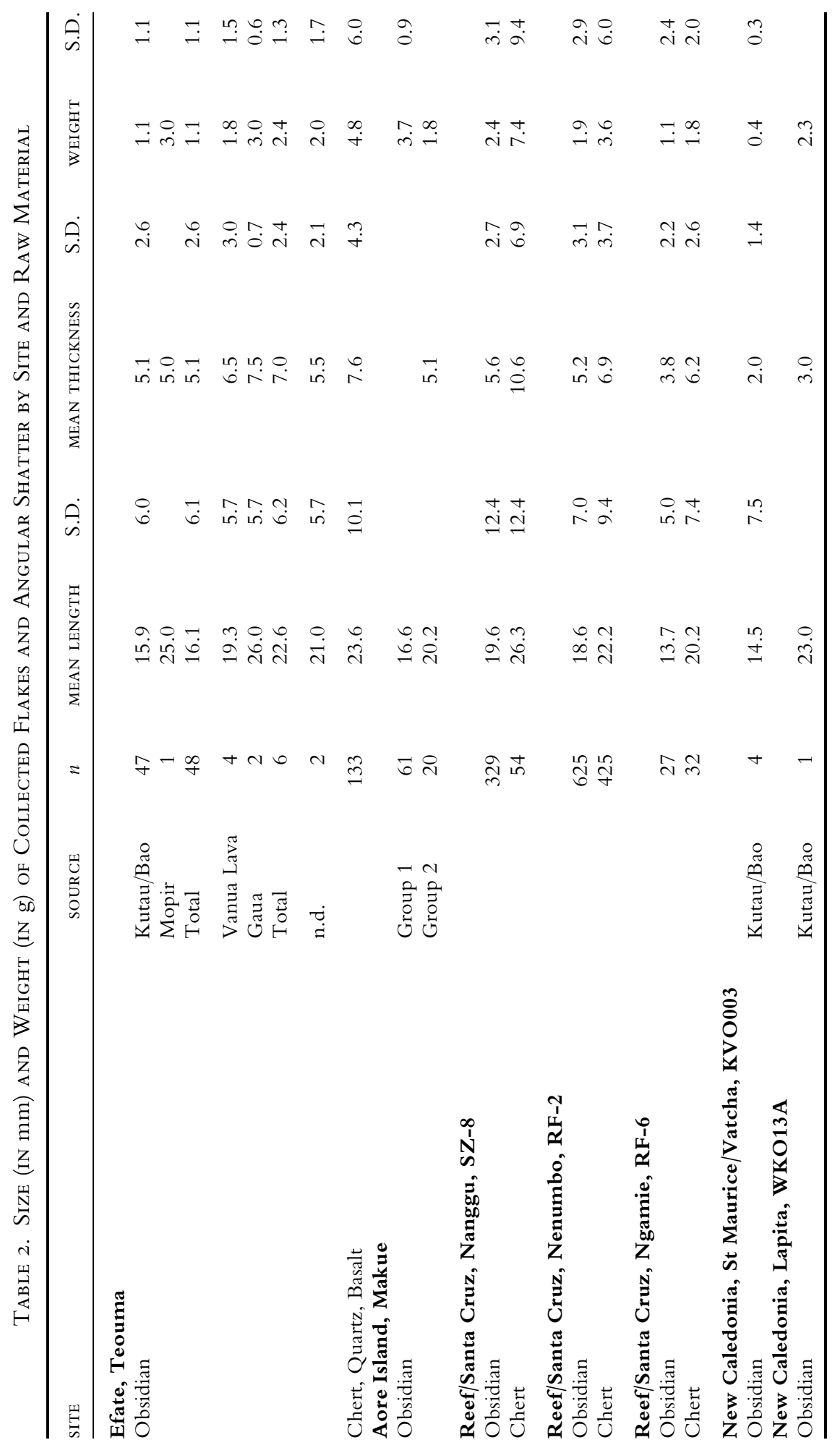



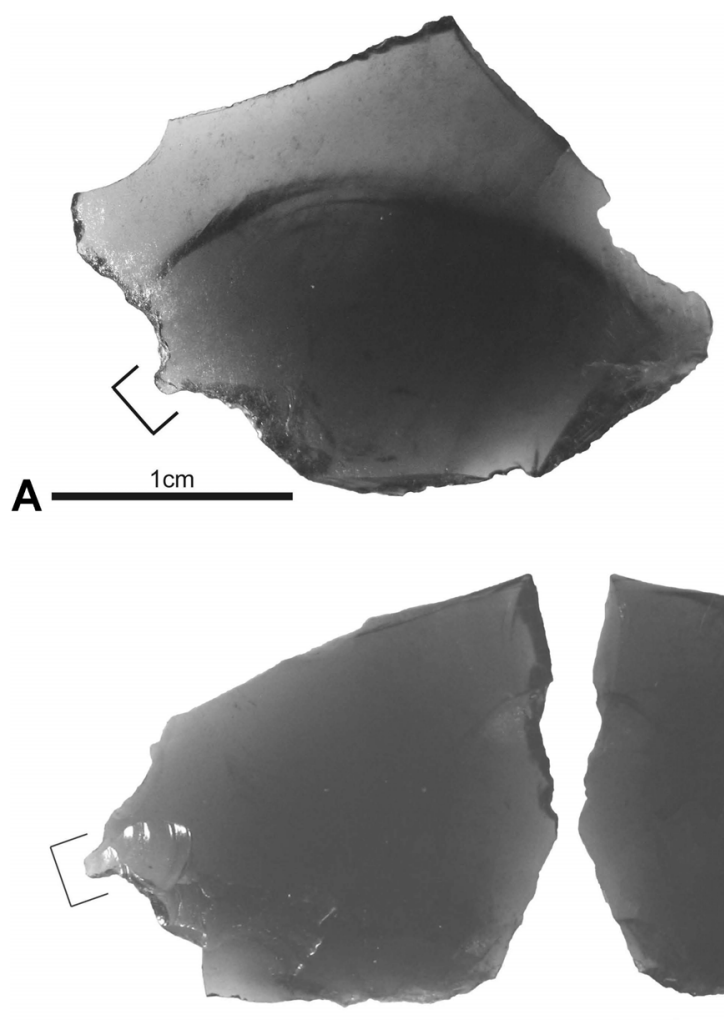

B

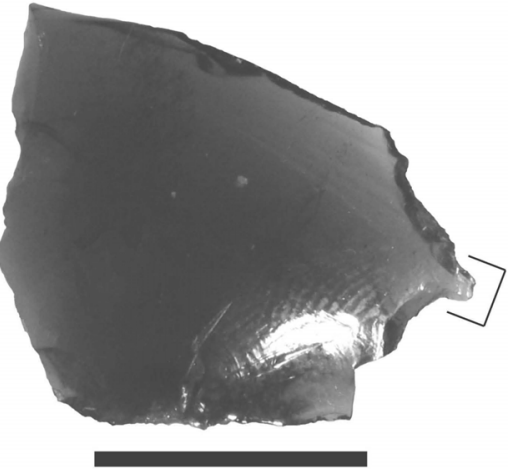

$1 \mathrm{~cm}$

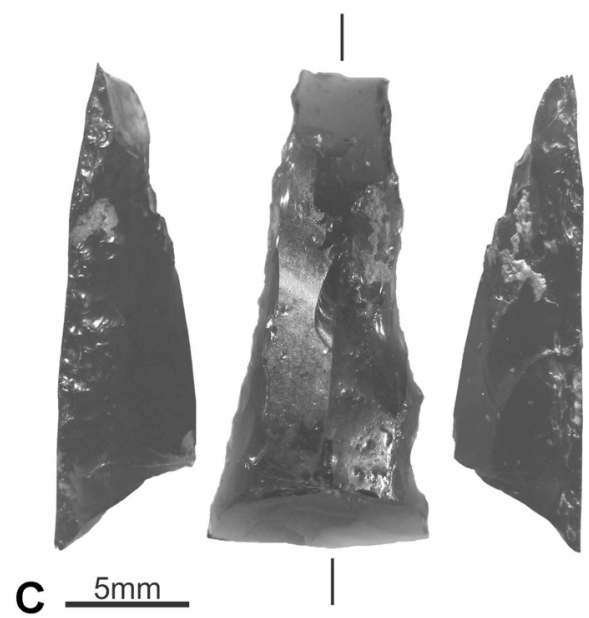

Fig. 4. (A) Artifact 6.855, "Graver," dorsal side, graver point indicated through bracket; (B) Artifact 6.907, "Graver," dorsal and ventral surface, graver point indicated through brackets; (C) Artifact 5.123 , "backed point" with impact breakage on distal end. 
On the other hand, they show a similar percentage of breakages $(33.3 \%$ complete, $16.7 \%$ transverse, $16.7 \%$ lengthwise, and $33.3 \%$ both) to the WNB obsidian artifacts. Half of the artifacts have traces of cortex. Both pieces from the subsource of Gaua are carrying cortex, one in primary and one in tertiary location. The single artifact carrying cortex from the Vanua Lava subsource displays cortex on the platform. No formal tools could be identified, but all of the artifacts show traces of edge damage.

\section{Chert, Quartz, and Basalt}

Only a comparatively small percentage of the total weight of flaked lithic artifacts consists of obsidian artifacts $(9.8 \% ; 72.3 \mathrm{~g})$, with chert (84 pieces), quartz (25 pieces), and basalt (24 pieces) making up 90.2 percent $(639.8 \mathrm{~g})$ of the total weight. The relatively large number of cores (6 chert, 1 quartz, and 1 basalt), in combination with high amounts of cortex (here defined as unworked surface) on the flakes, suggests local sources.

Artifacts made from chert, quartz, and basalt are distributed equally throughout the sequence. Two artifacts were surface finds or from disturbed contexts. Forty artifacts were found in Layers 1 and 2 with a mean weight of $4.3 \mathrm{~g}$ (SD: $4.1 \mathrm{~g}$ ); in the interfaces of Layer $2 / 3$ and 1/3, 21 artifacts were found (mean weight $4.3 \mathrm{~g}$, SD: $4.2 \mathrm{~g}$ ); and Layer 3 contains 70 artifacts with a mean weight of $5.3 \mathrm{~g}$ (SD: $7.3 \mathrm{~g})$.

A similar issue arises as with the obsidian concerning stratigraphic attribution of the chert, quartz, and basalt. Although there is certainly some mixing of material found in Layers 1 and 2, and much of Layer 2/3 and 1/3 material is most probably attributable to the Layer 3 midden deposits, the distribution is somewhat different than that of obsidian. In contrast to the obsidian the other flaked materials are also found in the Erueti-only parts of the site nearer the river, and in undisturbed Layer 2 deposits excavated in 2008. In addition, similar chert and other flakes occur in the late Lapita-Erueti-period Arapus site in northwest Efate. Some of the non-obsidian flaked material from 2004-2006 is thus certainly attributable to the Erueti phase occupation at Teouma.

The amount of angular shatter (13 chert, 8 quartz, and 2 basalt) in the assemblage together with the high amount of primary and secondary cortex (defined after Andrefsky 2005); 32.3 percent of the artifacts are carrying cortex with an average of 39.8 percent of the dorsal side covered by cortex. The occurrence of eight cores indicate the production of flakes on site. The non-obsidian artifacts show edge damage less often: only 28 artifacts (21.1\%) displayed a fine retouch on one or more edges. Breakages are less common: 81.8 percent (90 pieces) of the analyzed flakes were complete, 13.6 percent (15 pieces) were transversally broken, and 4.5 percent ( 5 pieces) had both types of breakage.

Eight cores were found. As in other Lapita sites (Halsey 1995; Hanslip 2001; Sheppard 1993) they show free hand reduction technology with no striking platform preparation and no signs of standardized core reduction strategy. The mean weight of the cores is $10.4 \mathrm{~g}$ (SD: $9.3 \mathrm{~g}$ ) with an average length of $33.3 \mathrm{~mm}$ (SD: $15.4 \mathrm{~mm}$ ). The number of scars per core (Mean: 3.3, SD: 1.12) is positive proportional to the number of core rotations and terminations on flaking surfaces. Two 
cores showed traces of cortex, one with 20 percent cortex and one with 80 percent; this indicates a core that was tested and then discarded (Andrefsky 2005). Three cores showed bipolar reduction, not uncommon in many lithic industries (Odell 2000; Shott 1989b) and two cores were recycled flakes.

\section{DISCUSSION}

\section{Time and Range of West New Britain Obsidian Exchange}

The study of obsidian artifacts from Teouma is the first detailed geochemical analysis of a significant assemblage (48 pieces) of West New Britain (WNB) obsidian in Vanuatu. The radiocarbon dates for the Teouma site indicate that it was used from the initial colonization of Vanuatu around 3100 B.P., and again during the early Erueti phase lasting from about 2800 to 2500 B.P. The occupation ceased thereafter and no other use of the site, except for gardening, can be detected until about a century ago (Bedford et al. 2006:817). No obsidian artifacts were found in areas of the site containing only Erueti layers, so we believe that an import of WNB obsidian ceased some time prior to 2800 B.P. with the end of Lapita in Vanuatu.

The chronology of the Teouma obsidian assemblage can potentially help delineate the changes in the exchange pattern of obsidian through the eastern Bismarcks and the Solomons from a dominance of WNB obsidian in early Lapita to Admiralty Islands obsidian in middle Lapita and back to a dominance of WNB obsidian in latest Lapita (Summerhayes 2003, 2009; Summerhayes et al. 1998; White and Harris 1997). The WNB to Admiralties change is not seen in the large assemblages of the three main Reefs-Santa Cruz Lapita sites of SZ-8, RL-2, and RL-6 (Green 1987; Sheppard 1993). The later Lapita Kiki phase deposits on nearby Tikopia, however, contain only Admiralty and Banks Islands obsidians (Spriggs et al. submitted, correcting Kirch and Yen 1982), and may suggest that the obsidian source realignment is also witnessed in Remote Oceania. If so it must have occurred after obsidian use ceased at the Teouma site.

As larger assemblages usually account for a more intense exchange connection, we would expect that these changes in sources would be replicated by distant communities in direct contact with these regions. The dominance of Kutau/Bao obsidian throughout the Teouma sequence suggests that direct contact with colonizer communities in the eastern Bismarck Archipelago is unlikely. Small-scale interregional connections, such as intense exchange only to the Lapita sites in the Reefs-Santa Cruz Islands appear to be the most plausible model in light of the low mean weight of the artifacts, the missing cores and cortex, and the large numbers of dorsal scars on the artifacts.

Sand and Sheppard $(2000: 240)$ argued that the exchange network of WNB obsidian "was very quickly broken" beyond the Reefs-Santa Cruz Group. This model now needs to be amended. Bedford and Spriggs proposed "Rather than the Reefs-Santa Cruz Group being seen as unique, it can now be seen rather as a nodal point and not a terminus in a wider chronozone stretching down to northern and central Vanuatu" (2008:105). This is apparent through the discovery of significant WNB obsidian assemblages in northern and central Vanuatu and the exchange of Banks Islands obsidian into the Southeast Solomon Islands, starting 
from the earliest Lapita colonization onward in this region (see also Sheppard and Walter 2006:59). Whether this interaction sphere continues into the post-Lapita phase requires further dating and analysis of southeast Solomons assemblages. That it either did continue or was later revived is evident through the significant amounts of Banks Islands obsidian found in Tikopia in deposits of the last thousand years (Kirch and Yen 1982:256, Table 35).

To date only a single piece of Admiralties obsidian has been identified geochemically in Vanuatu, in this case by Neutron Activation Analysis (Ambrose 1976:365-366), from Lapita contexts on the island of Malo. In itself it is not evidence of continued exchange relations with the Bismarcks in later Lapita times, as there was a small component of Admiralties obsidian accompanying the predominantly WNB obsidians during initial occupation of the Reefs-Santa Cruz sites. Galipaud and Swete-Kelly (2007) have proposed additional imports of Admiralty Islands obsidian into Vanuatu based on density measurements on the Makue artifacts. A detailed geochemical analysis of these artifacts is still pending, but the limitations of the density method (Swete-Kelly 2001; Torrence and Victor 1995), such as the large overlap of Admiralty Islands obsidian and obsidian from the Banks Islands (Spriggs et al. 2010), makes this suggested provenance questionable.

As noted earlier no obsidian from Mopir has been found in the southeast Solomon Islands (Green 1987:244), whereas it is present in later Lapita assemblages in the eastern Bismarck Archipelago. The possible implications of the single piece of Mopir obsidian found at Teouma, although in unclear stratigraphical deposition, need to be considered. First it could support a continued communication between Remote Oceania and the Bismarck Archipelago into the latest Lapita period as already suggested on other grounds by Sheppard (1993:134). Alternatively it might open the possibility of a renewed exchange connection with the Bismarck Archipelago toward the end of the Lapita period. Less likely is that it is a residual piece, somehow incorporated into early Lapita obsidian exchanges, as no Mopir obsidian is found in early Lapita sites anywhere in the Bismarcks (Summerhayes 2003:138, $2004: 150,2009$; Summerhayes et al. 1993: Table 4).

\section{Modes of Exchange}

Unsurprisingly for the site's distance from the source, the Teouma artifacts are small with minimal cortex detectable. The lack of cores and three pieces of angular shatter provide evidence of only very minor production of artifacts at the site and make import of already flaked artifacts into the site perhaps more likely. Whether this apparent picture is due to the concentration of the fieldwork to date on the cemetery area as opposed to the earliest Lapita midden deposits is the subject of current research. One indication that it might be a sampling issue is the analysis of the obsidian assemblage of Makue, where production of artifacts could be unambiguously identified (Jean-Christophe Galipaud and Marie-Clare SweteKelly pers. comm.), although the publication of the detailed technological analysis of that assemblage is still pending.

The low mean weight of the artifacts and the missing cortex as well as a high amount of dorsal scars could indicate down-the-line exchange (Renfrew 1975) 
with other Lapita colonization communities closer geographically to the source. Specht (2002) in his comparative study of obsidian exchange from Lapita and post-Lapita sites has, however, discussed the problems of comparing mean weight of artifacts from different sites with one another (cf. also Fredericksen 1997; Torrence 1986). In the same study Specht showed the connection between downthe-line exchange and a "pulse" of colonization in early Lapita times (cf. also Irwin and Holdaway 1996).

Outside Vanuatu, geographically closest sites in a down-the-line exchange would be the Lapita sites in the Reefs-Santa Cruz Islands. Total weight of imported Kutau/Bao obsidian (Sheppard 1993:127), mean weight of the artifacts (Table 2), the occurrence of cores (Sheppard 1993:129, Table 5), and cortex on cores and artifacts (SZ-8, 32\%; RF-2, 29.4\%; RF-6, 45.8\%; cf. Sheppard 1993:125) are additional arguments for an exchange model in which the Reefs-Santa Cruz sites would be defined as nodal points in this exchange network.

\section{Social Implications}

Exchange networks that were based on the necessity to acquire a valued commodity tend to display economization, and this has been shown on occasion in relation to obsidian artifact reduction (Torrence 2005). However, several examples of "non-economical" utilization of obsidian in Remote Oceania have been identified (Green 1976; Halsey 1995; Sheppard 1993; Swete-Kelly 2001). It seems that the Teouma assemblage also fits into this category. Because of such examples, Swete-Kelly stated that the mechanism involved in obsidian exchange cannot be explained through a strictly formalist economic theory $(2001: 98)$.

If obsidian was discarded in a "most utilitarian way" (Green and Anson 1998:66) at Teouma, the pattern is hard to interpret. The absence of retouch on the artifacts and their discard before usability was fully exhausted (some of the artifacts still contain sharp edges), could be interpreted as discard "according to another set of commodity (utilitarian) values" (Sheppard 1993:135). There is, however, also the possibility that the main function of the artifacts could only be fulfilled in the most "fresh" stage of reduction.

Specht (2002:45) argued that such seemingly non-utilitarian behavior shows "the capacity of the colonists to continue using obsidian in the same way as in their ancestral home" and, further, provides a witness of "the conscious attempts to replicate the ancestral societies" (Specht 2002:44). In addition, Torrence (2005:365) explains this behavior through the physical attributes of obsidian, its "brilliance, translucency and strong colour" together with the "uniqueness of its source" (see also Green and Kirch 1997; Kirch 1988; Sheppard 1993; Sheppard and Walter 2006).

Banks Islands obsidian was only infrequently employed as a substitute for the WNB material, indicating the different value given to particular obsidian sources (Torrence and Summerhayes 1997). Thus, it provides an additional argument for the importance of obsidian as one of the links to a common homeland or tradition. It may also be an indicator of the need for replication of ancestral traditions 
as a means of risk-minimization (Bedford and Spriggs 2008:99) and stronger bonding of the group in an unknown and therefore dangerous territory during the initial colonization phase (Torrence 2004).

\section{CONCLUSION}

Although no sourcing study has been carried out on the cherts, quartz, and basalt flaked material, it appears likely that it is nearly all of local origin. This is on the basis of the number of cores, the high amounts of cortex, and the size of individual artifacts. This range of materials continued in use throughout the prehistoric sequences of central Vanuatu. In contrast, obsidian export from West New Britain represents one of the most distant transports of a raw material among Neolithic societies (Bellwood and Hiscock 2005). Although a less prominent cultural marker than the fine decoration on Lapita vessels, it is the only commodity that traveled the whole distance from the founding communities in the Bismarck Archipelago to the colonizer settlements of western Remote Oceania in any quantity (Green and Kirch 1997: Table 2.2).

The modes of exchange of this material become clearer when we see the Teouma site in its wider context. The physical attributes of the artifacts and the lack of cores indicate a down-the-line exchange with neighboring sites closer to the source area. The small size of the artifacts (as is also the case in the early Lapita site of Makue on Aore) and the low amount of cortex and high count of dorsal scars suggest that direct contact with the source areas is unlikely. An interaction sphere involving the Reefs-Santa Cruz Islands seems to be more probable. This can also be detected in common decorative traits on Lapita vessels (Bedford 2007) as well as in the occasional presence of Banks Islands obsidian in these sites.

Re-creating known social worlds in an unknown territory is a challenge for human groups (Anderson 2003). That such re-creation could not be fulfilled by local obsidian resources is possibly indicated by the low utilization of the Banks Islands obsidian, although the Teouma assemblage shows that the Banks sources were known and used from the time of initial settlement. Although the boundary of Banks Islands obsidian exchange has been pushed farther south by the Teouma discoveries, we still have no evidence that these obsidians were exchanged into the "southern" Lapita province as defined by Sand (2000). The presence of obsidians at the Teouma site might be viewed as a by-product of more encompassing exchange relations, bringing in marriage partners along with a range of goods of social value. Obsidian itself cannot be considered as of lasting intrinsic value; if it were, the exchange of at least the locally available Banks Islands products would have continued to central Vanuatu into the post-Lapita period. As a reminder of the Bismarcks homeland or as a by-product of continued indirect interaction with it, the utilization of obsidian in central Vanuatu was a very short-lived phenomenon.

\section{ACKNOWLEDGMENTS}

This project was funded by Australian Research Council grant DP0556874. We would like to thank Charlotte Allen and Frank Brink for their help in running the geochemistry analysis. 


\section{REFERENCES CITED}

Ambrose, W. R.

1976 Obsidian and its prehistoric distribution in Melanesia, in Ancient Chinese Bronzes and South east Asian Metal and other Archaeological Artifacts: 351-378, ed. N. Barnard. Melbourne: National Gallery of Victoria.

ANDERSON, A.

2003 Uncharted waters: Colonization of remote Oceania, in Colonization of Unfamiliar Landscape: 169-189, ed. M. Rockman and J. Steele. London: Routledge.

ANDREFSKY, W.

2005 Lithics: Macroscopic Approaches to Analysis. Cambridge and New York: Cambridge University Press.

Anson, D.

2000 Excavations at Vunavaung (SDI), Rakival Village, Watom Island, Papua New Guinea. New Zealand Journal of Archaeology 20:95-118.

BAXTer, M. J.

2006 A review of supervised and unsupervised pattern recognition in archaeometry. Archaeometry $48(4): 671-694$.

BEDFORD, S.

2007 Crucial first steps into Remote Oceania, in From Southeast Asia to the Pacific: Archaeological Perspectives on the Austronesian Expansion and the Lapita Cultural Complex: 185-205, ed. S. Chiu and C. Sand. Taipei: Centre for Archaeological Studies.

Bedford, S., A. Hoffman, M. Kaltal, R. Regenvanu, and R. Shing

2004 Dentate-stamped Lapita reappears on Efate, central Vanuatu: A four decade-long drought is broken. Archaeology in New Zealand 47(1):39-49.

Bedford, S., And M. Spriggs

2002 Of Shell, Bone and Stone. A Review of Non-Ceramic Artefacts Recovered from the First 1000 Years of Vanuatu's Archaeological Record, in Fifty Years in the Field: Essays in Honour and Celebration of Richard Shutler Jr.'s Archaeological Career: 135-152, ed. S. Bedford, C. Sand, and D. Burley. Auckland: New Zealand Archaeological Association Monograph.

2008 Northern Vanuatu as a Pacific crossroads. The archaeology of discovery, interaction, and the emergence of the ethnographic present. Asian Perspectives 47(1):95-120.

Bedford, S., M. Spriggs, H. R. Buckley, F. Valentin, and R. Regenvanu

2009 The Teouma Lapita site, South Efate, Vanuatu: A summary of three field seasons (20042006), in Lapita: Ancestors and Descendants: 215-234, ed. P. J. Sheppard, T. Thomas, and G. R. Summerhayes. Auckland: New Zealand Archaeological Association Monograph Series.

Bedford, S., M. Spriggs, and R. Regenvanu

2006 The Teouma Lapita site and the early human settlement of the Pacific Islands. Antiquity $80: 812-828$.

Bellwood, P., ANd P. Hiscock

2005 Australia and the Austronesians, in The Human Past: 264-305, ed. C. Scarre. London: Thames and Hudson.

Bellwood, P., ANd P. KoON

1989 Lapita colonists leave boats unburned! The questions of Lapita links with Island South East Asia. Antiquity 63:613-622.

BEST, S.

1987 Long-distance obsidian travel and possible implications for the settlement of Fiji. Archaeology in Oceania $22: 31-32$.

Fredericksen, C.F.K.

1997 The maritime distribution of Bismarck Archipelago obsidian and Island Melanesian Prehistory. Journal of the Polynesian Society 106:375-393.

Galipaud, J.-C., And M. C. Swete-Kelly

2007 Makue (Aore Island, Santo, Vanuatu): A new Lapita site in the ambit of New Britain obsidian distribution, in Oceanic Explorations: Lapita and Western Pacific Settlement: 151-162, ed. S. Bedford, C. Sand, and S. P. Connaughton. Canberra: Terra Australis 26, ANU E Press. 
Green, R. C.

1976 Lapita sites in the Santa Cruz group, in Southeast Solomon Islands Cultural History: 245265, ed. R. C. Green and M. M. Cresswell. Wellington: Royal Society of New Zealand Bulletin.

1987 Obsidian results from the Lapita sites of the Reef/Santa Cruz Islands, in Archaeometry: Further Australasian Studies: 239-249, ed. W. R. and J.M.J. Mummery. Canberra: Occasional Papers in Prehistory 14. RSPAS and ANU.

Green, R. C., And D. Anson

1998 Excavations at Kainapirina (SAC), Watom Island, Papua New Guinea. New Zealand Journal of Archaeology $20: 29-94$.

Green, R. C., And P. V. Kirch

1997 Lapita exchange systems and their Polynesian transformations: Seeking explanatory models, in Prehistoric Long-Distance Interaction in Oceania: An Interdisciplinary Approach: 19-37, ed. M. I. Weisler. Auckland: New Zealand Archaeological Association Monograph 21.

Halsey, A.

1995 Obsidian Resource Maximisation. A Comparison of Two Lapita Assemblages. Unpublished B.A. (Honors) Thesis. La Troube University, Melbourne.

HANSLIP, M. D.

2001 Expedient Technologies? Obsidian Artefacts in Island Melanesia. Unpublished Ph.D. Thesis. Australian National University, Canberra.

HiscOCK, P.

2002 Quantifying the size of artefact assemblages. Journal of Archaeological Science 29(3):251258.

IRWIN, G., AND S. HOLDAWAY

1996 Colonisation, trade and exchange: From Papua to Lapita, in Oceanic Culture History: Essays in Honour of Roger Green: 225-235, ed. J. Davidson, G. Irwin, B. F. Leach, A. Pawley, and D. Brown. Auckland: New Zealand Journal of Archaeology Special Publication.

JugGins, S.

2005 C2 Data Analysis 1.4.2. Newcastle: University of Newcastle.

KIRCH, P. V.

1988 Long-distance exchange and island colonization: The Lapita case. Norwegian Archaeological Review 21(2) : 103-117.

KIRCH, P. V., AND D. E. YEN

1982 Tikopia: The Prehistory and Ecology of a Polynesian Outlier. Honolulu: Bishop Museum Press.

LentFer, C., And R. TORrence

2007 Holocene volcanic activity, vegetation succession, and ancient human land use: Unraveling the interactions on Garua Island, Papua New Guinea. Review of Palaeobotany and Palynology 143: 83-105.

LONGerich, H. P., S. E. Jackson, AND D. GÜNTher

1996 Laser Ablation Inductively Coupled Plasma Mass Spectrometric transient signal data acquisition and analyte concentration calculation. Journal of Analytical Atomic Spectrometry $11: 899-904$.

ODell, G. H.

1981 The mechanics of use-breakage of stone tools: Some testable hypotheses. Journal of Field Archaeology 8(2): 197-209.

2000 Stone tool research at the end of the millennium: Procurement and technology. Journal of Archaeological Research 8(4):269-331.

Petrie, C. A., And R. Torrence

2008 Assessing the effects of volcanic disasters on human settlement in the Willaumez Peninsula, Papua New Guinea: A Bayesian approach to radiocarbon calibration. The Holocene $18(5): 729-744$.

REEPMEYER, C.

2008 Characterising volcanic glass sources in the Banks Islands, Vanuatu. Archaeology in Oceania 43(3): 120-127. 
2009 Obsidian Sources and Distribution Systems Emanating from Gaua and Vanua Lava on the Banks Islands of Vanuatu. Unpublished Ph.D. Thesis. Australian National University, Canberra.

Renfrew, A. C.

1975 Trade as action at a distance: Questions of integration and communication, in Ancient Civilization and Trade: 3-59, ed. J. A. and C. C. Lamberg-Karlovsky. Albuquerque: University of New Mexico Museum Press.

SAND, C.

2000 The specificities of the "Southern Lapita Province": The New Caledonian case. Archaeology in Oceania 35(1):20-33.

SAnd, C., ANd P. J. Sheppard

2000 Long distance prehistoric obsidian imports in New Caledonia: Characteristics and meaning. Earth and Planetary Sciences $331: 235-243$.

SHEA, J. J.

1988 Spear points from the Middle Palaeolithic of the Levant. Journal of Field Archaeology 15(4) : 441-450.

Sheppard, P. J.

1992 A report on the flaked lithic assemblages from three Southeast Solomons Lapita sites (SESZ-8, SE-RF-2, SE-RF-6), in Poterie Lapita et Peuplement: 145-153, ed. J.-C. Galipaud. Nouméa: ORSTOM.

1993 Lapita lithics: Trade/exchange and technology. A view from the Reefs/Santa Cruz. Archaeology in Oceania 28:121-137.

1996 Hard rock: Archaeological implications of chert sourcing in Near and Remote Oceania, in Oceanic Culture History: Essays in Honour of Roger Green: 99-115, ed. J. Davidson, G. Irwin, B. F. Leach, A. Pawley, and D. Brown. Auckland: New Zealand Journal of Archaeology Special Publication.

Sheppard, P. J., AND R. WALter

2006 A revised model of Solomon Islands culture history. Journal of the Polynesian Society $115(1): 47-76$.

Sнотт, M. J.

1989a On tool-class use lives and the formation of archaeological assemblages. American Antiquity 54(1):9-30.

19896 Bipolar industries: Ethnographic evidence and archaeological implications. North American Archaeologist 10(1): 1-24.

Speakman, R. J., and H. NefF

2005 The application of Laser Ablation ICP-MS to the study of archaeological materials-An introduction, in Laser Ablation ICP-MS in Archaeological Research: 1-14, ed. R. J. Speakman and H. Neff. Albuquerque: University of New Mexico Press.

SPECHT, J.

2002 Obsidian, colonising and exchange, in Fifty Years in the Field: Essays in Honour and Celebration of Richard Shutler Jr.'s Archaeological Career: 37-49, ed. S. Bedford, C. Sand, and D. Burley. Auckland: New Zealand Archaeological Association Monograph 25.

SPRIGGS, M., AND S. BEDFORD

2001 Arapus: A Lapita site at Mangaasi in central Vanuatu? in The Archaeology of Lapita Dispersal in Oceania: Papers from the Fourth Lapita Conference: 93-104, ed. G. R. Clark, A. Anderson, and T. Vunidilo. Canberra: Terra Australis 17, Pandanus Books.

Spriggs, M., J. R. Bird, ANd W. R. Ambrose

2010 A Reanalysis of the Tikopia obsidians, Archaeology in Oceania 45(1):31-38.

SPSS

2000 SPSS 12.0 for Windows. Chicago: SPSS Inc.

Summerhayes, G. R.

2003 The rocky road: The selection and transport of Admiralties obsidian to Lapita communities. Australian Archaeology $57: 135-142$.

2004 The nature of prehistoric obsidian importation to Anir and the development of a 3,000 year old regional picture of obsidian exchange within the Bismarck Archipelago, Papua New Guinea. Records of the Australian Museum Supplements 29:145-156. 
2009 Obsidian network patterns in Melanesia-Sources, characterisation and distribution. IndoPacific Prehistory Association Bulletin 29:109-124.

Summerhayes, G. R., And J. Allen

1993 The transport of Mopir obsidian to late Pleistocene New Ireland. Archaeology in Oceania 28(3): 144-148.

Summerhayes, G. R., J. R. Bird, R. Fullagar, C. Gosden, J. Specht, and R. Torrence

1998 Application of PIXE-PIGME to archaeological analysis of changing patterns of obsidian use in West New Britain, Papua New Guinea, in Archaeological Obsidian Studies: Method and Theory: 129-158, ed. M. S. Shackley. New York: Plenum Press.

Summerhayes, G. R., C. Gosden, R. Fullagar, J. Specht, R. Torrence, J. R. Bird, N. ShaGHOLI, AND A. KATSAROS

1993 West New Britain obsidian: Production and consumption patterns, in Archaeometry: Current Australasian Research: 57-68, ed. B. L. Fankhauser and J. R. Bird. Canberra: RSPAS and Australian National University.

Swete-Kelly, M. C.

2001 Lapita Lithics: An Analysis of Obsidian Acquisition, Utilisation and Discard on the Anir Islands. Unpublished B.A. (Honors) Thesis. Australian National University, Canberra.

TIXIER, J.

1974 Glossary for the Description of Stone Tools. Translated by M. H. Newcomer. San Antonio: The Center for Archaeological Research, University of Texas.

Torrence, R.

1986 Production and Exchange of Stone Tools: Prehistoric Obsidian in the Aegean. Cambridge and New York: Cambridge University Press.

2004 Now you see it, now you don't: Changing obsidian source use in the Willaumez Peninsula, Papua New Guinea, in Explaining Social Change: Studies in Honour of Colin Renfrew: 115-125, ed. J. Cherry, C. Scarre, and S. Shennan. Cambridge: McDonald Institute Monographs.

2005 Valued stone-how so?, in Many Exchanges: Archaeology, History, Community and the Work of Isabel McBryde: 357-372, ed. I. Macfarlane, M.-J. Mountain, and R. Paton. Canberra: Aboriginal History Monograph 11.

Torrence, R., C. Pavlides, P. Jackson, and J. Webb

2000 Volcanic disasters and cultural discontinuities in the Holocene of West New Britain, Papua New Guinea, in The Archaeology of Geological Catastrophes: 225-244, ed. B. McGuire, D. Griffiths, and I. Stewart. London: Geological Society Special Publications.

Torrence, R., J. Specht, R. Fullagar, and J. R. Bird

1992 From Pleistocene to present: Obsidian sources in West New Britain, Papua New Guinea. Records of the Australian Museum Supplement 15:83-98.

Torrence, R., and G. R. Summerhayes

1997 Sociality and the short distance trader: Intra-regional obsidian exchange in the Willaumez region, Papua New Guinea. Archaeology in Oceania 32(1): 74-84.

Torrence, R., AND K. L. Victor

1995 The relativity of density. Archaeology in Oceania 30:121-131.

White, J. P., AND M. N. Harris

1997 Changing sources: Early Lapita period obsidian in the Bismarck Archipelago. Archaeology in Oceania 32 : 97-107.

WICKLER, S.

2001 The Prehistory of Buka: A Stepping Stone Island in the Northern Solomons. Canberra: Terra Australis $16, \mathrm{ANH}$ and CAR.

Young, D. E., AND D. B. BAmForth

1990 On the macroscopic identification of used flakes. American Antiquity 55(2):403-409.

\section{ABSTRACT}

Fifty-six obsidian artifacts and 141 non-obsidian artifacts were excavated in three field seasons at Teouma, Efate Island, central Vanuatu. Using LA-ICP-MS the 
majority of the obsidian artifacts were provenienced to the obsidian subsource of Kutau/Bao on West New Britain in the Bismarck Archipelago, Papua New Guinea. This study is the first geochemical analysis of a significant assemblage of West New Britain obsidian south of the Solomon Islands. Moreover, this finding represents only the second sizable assemblage of West New Britain obsidian in Remote Oceania beyond the Reefs-Santa Cruz Lapita sites and further establishes Vanuatu as a key area in understanding the initial Lapita settlement of Remote Oceania. Six obsidian artifacts were sourced to the Banks Islands, northern Vanuatu, supporting the hypothesis that sources there were known and utilized from the initial colonization of the Vanuatu Archipelago. A single artifact from the West New Britain subsource of Mopir was found. This is the only Lapita-period Mopir obsidian artifact found so far outside the Bismarck Archipelago. The geochemical analysis was accompanied by a quantitative attribute analysis investigating the reduction technology of the flaked assemblage. KeYwords: provenance studies, obsidian exchange, Vanuatu, Lapita, colonization, western Melanesia. 